\title{
The role of cooperation for improved stewardship of marine social-ecological systems in Latin America
}

\author{
Sebastián Villasante $^{1}$ and Henrik Österblom ${ }^{2}$
}

\begin{abstract}
Latin American and Caribbean (LAC) countries are among the worlds' richest in marine biodiversity. Fish stocks in these regions are important for fishing communities, and fishing activities engage several million people. These fisheries depend on the natural services provided by a diverse range of marine social-ecological systems, but many LAC fisheries are in a degraded state, and concerns about overexploitation are widespread. With most fishery resources fully exploited or overexploited, opportunities for development lie primarily in restoring depleted stocks and using stocks more efficiently. The papers published in the Special Feature "Cooperation, Local Communities, and Marine Social-Ecological Systems: New Findings from Latin America" present a range of experiences with ecosystem stewardship in the region and highlight promising perspectives for the future. The Special Feature consists of papers that deal with new findings from case studies which show how cooperation is key for building resilience in LAC fisheries. These case studies illustrate the effects of different types of cooperation and the roles of diverse stakeholders (fishers, scientists, environmental nongovernmental organizations, and national administrations, among others) in different countries of the region. Combined, these papers describe social processes, leadership, and institutional and organizational changes of relevance for stewardship of marine social-ecological systems in Latin America. The field of resilience research is still in an explorative phase in the region, and our ambition with this Special Feature is that the new discoveries presented may stimulate additional research in this field, including increased international cooperation with LAC scientists.
\end{abstract}

RESUMEN. Los países de América Latina y El Caribe concentran una de las áreas de mayor biodiversidad marina del mundo. Las pesquerías comerciales en estas regiones aportan una elevada fuente de ingresos económicos para millones de personas. A pesar de que estas pesquerías dependen de los servicios ecosistémicos aportados por una gran variedad de sistemas marinos socio-ecológicos, gran parte de ellas continúan degradándose, y la preocupación por reducir la sobreexplotación está ampliamente extendida entre la comunidad científica. Con la mayoría de los stocks completamente explotados o sobreexplotados, las oportunidades para el desarrollo de las pesquerías dependen fundamentalmente en la recuperación de los stocks a través de su uso más racional. Los trabajos publicados en este monográfico "Cooperation, Local Communities, and Marine Social-Ecological Systems: New Findings from Latin America" presentan una variedad de experiencias e gestión pesquera en la región y resaltan perspectivas y resultados prometedores para el futuro de la región. El monográfico incluye trabajos muestran, desde diferentes disciplinas, enfoques y metodologías, que la cooperación resulta clave para la resiliencia de las pesquerías comerciales de América Latina y El Caribe. Estos casos de estudio ilustran los efectos de la cooperación entre diferentes grupos de usuarios (pescadores, científicos, organizacionales no gubernamentales, gobiernos locales, regionales y nacionales) así como los roles desempeñados por éstos en varios países de la región. Combinados, estos trabajos describen procesos sociales, el rol de líderes locales así como cambios institucionales y organizacionales de gran relevancia para la gestión de los sistemas marinos socio-ecológicos de la región. El campo de investigación de la resiliencia aun se encuentra en una fase de exploración en la región, y nuestra ambición con este monográfico consiste en estimular aun más la investigación en este campo a través de una mayor cooperación científica internacional con científicos de América Latina y El Caribe.

Key Words: cooperation; Latin America; marine social-ecological systems; stewardship

\section{INTRODUCTION}

Latin American and Caribbean (LAC) countries provide fish stocks of critical importance for millions of individuals and thousands of fishing communities (Defeo and Castilla 2005). These fish stocks are produced in some of the most diverse ecosystems of the world (Bovarnick et al. 2010), which emphasizes the need for ecosystem stewardship that can contribute to securing functioning and resilient marine social-ecological systems. Ecosystem stewardship that enables a capacity to respond to rapid and unexpected dynamics is critical for sustained and improved human well-being (Chapin et al. 2010). However, many LAC fisheries are rapidly becoming increasingly degraded (Boyd 2010), in part as a consequence of open access and limited cooperation. Consequently, concerns about overexploitation of LAC fisheries are widespread (Boyd 2010, Defeo and Castilla 2012).
Of the 49 stocks for which data are officially available, $2 \%$ are considered to be underexploited and $10 \%$ are moderately exploited, with some potential for increased production (Boyd 2010). About $30 \%$ of stocks are moderately to fully exploited, and therefore, close to their maximum sustainable limits; a further $12 \%$ are fully exploited to overexploited (Bovarnick et al. 2010, Boyd 2010). About one-third (35\%) of fisheries are overexploited or depleted, while 10\% are recovering (Boyd 2010). For example, the biomass of one of the most important commercial fisheries in the region, the Argentinean hake (Merluccius hubbsi), is at a critical level. Such depletion has dramatic socioeconomic consequences for the national industry, but there is also substantial potential for increasing economic yields through better management (Villasante 2012). 
Global and local experiences demonstrate that noncooperative fisheries management incentives and insecure access to fisheries resources (Munro 1979, Ostrom 1990) often lead to overfishing, development of overcapacity, and a race to fish (Hilborn and Walters 1992, Bovarnick et al. 2010). With most fishery resources fully exploited or overexploited, opportunities for development lie primarily in restoring depleted stocks and using stocks more efficiently (Castilla and Defeo 2001, Gelcich et al. 2010, Villasante 2012). Most of the LAC fisheries have been developed under open access regimes with unauthorized extraction (including recreational fishing), which has made these systems readily accessible to free riders, competition, and conflicts, e.g., between small-scale, industrial, and recreational fleets (Salas et al. 2007).

Governance, a key component in sustainability, faces many challenges (Hughes et al. 2005, Chapin et al. 2011). These challenges stem from the fact that the world is highly interconnected and fast paced, and social-ecological interactions can have cascading effects at both local and global scales (Crèpin et al. 2011, Folke et al. 2011). The recent adoption by national governments of comanagement tools as an integral part of their fisheries policies is providing increased potential for innovation and experimentation of novel governance approaches. Studies of such experimentation provide informative case studies that contribute to the development of the theory and empirical research regarding comanagement and other forms of ecosystem stewardship (Castilla and Defeo 2001, Orensanz et al. 2005, Chapin et al. 2010). Management of marine resources is moving away from traditional top-down and single-stock strategies and towards bottom-up and ecosystem-based stewardship. This shift towards bottom-up governance of resources can be enhanced through the use of comanagement policy frameworks (Gelcich et al. 2010). Gutiérrez et al. (2011) have investigated factors that contribute to the success of comanagement initiatives in Latin American countries and elsewhere. Relevant factors, especially for meeting social-ecological goals in small-scale fisheries, include trust, cooperation, leadership, and community cohesion (Polasky et al. 2006, Boyd 2010, Gutiérrez et al. 2010, Cinner et al. 2012).

\section{THIS SPECIAL FEATURE}

Many governments and civil society are currently engaged in the development of collaborative governance approaches (Hilborn et al. 2005, Cinner et al. 2012). The case studies presented in this Special Feature include active participatory processes of stakeholders (fishers, scientists, environmental nongovernmental organization [NGOs], and national administrations, among others) in different countries of the region. Indeed, the LAC region is probably home to a wider variety of comanagement systems than anywhere else in the world. The progress achieved in developing ecosystem stewardship as presented in this Special Feature shows a mosaic of different levels of cooperation-many of which were inspired and led by members of the scientific community.

The papers published in this Special Feature present a range of experiences in the region, with promising perspectives for challenges of the future. The Special Feature consists of papers that deal with new findings from case studies which underline that the role of cooperation is key in building resilience in fisheries governance of LAC countries.

Arias Schreiber and Halliday (2013) examine the evolution of the Peruvian anchoveta (Engraulis ringens) fishery-the largest commercial single-species fishery in the world (FAO 2012) under the lens of the seven institutional design principles laid down by Ostrom (1990). This study confirms the value of these design principles as a valuable tool for analyzing and understanding large-scale common pool resource systems. In this case study, clearly defined user boundaries, collective choice arrangements, and nested enterprises were, however, not required to achieve sustainability, as is often the case. This paper shows how the Peruvian government has relaxed the user boundaries but instead focused on defining the amount of resources that the users are allowed to withdraw. This has been achieved through a quota system that is designed to guarantee the natural replenishment of the resource.

Basurto et al. (2013) study the role of cooperation in 12 small communities in the Gulf of California that have similar characteristics of certain aspects, including dependence on marine resources, fishing traditions, and socioeconomic homogeneity. The authors conclude that access to fishing permits and markets were the main reasons for fishers to form cooperatives in the areas studied. In addition, the authors conclude that communities that have had positive experiences of working together in the past build social capital and are more likely to invest in the transaction costs associated with forming and maintaining fishing cooperatives. Positive experiences of successful collective action can be conducive to building networks of individuals who share similar norms regarding the type of behavior that is expected.

Cinti et al. (2014) investigate the performance of formal and informal institutions in two rural communities in Baja California (Mexico) and their effect on fisheries sustainability by using the Institutional Analysis and Development Framework developed by Ostrom (1990). The authors found that unsecured tenure rights and lack of government support for enforcement are key elements for the observed outcomes in these small-scale fisheries. The authors recommend that the creation of communal property or use rights might provide an alternative to the security of tenure to fishers, might help protect local fishing grounds from unwanted visitors, and might incentivize local fishers to organize themselves to adopt and self-enforce fisheries management measures that are better adapted to their particular situations.

Rocha and Pinkerton (2015) investigate two Brazilian initiatives that have involved Venus clam (Anomalocardia brasiliana) comanagement during the last 20 years in two marine socialecological systems. This analysis contributes to the international discussion on participatory local-level resource management and calls attention to clams, a resource traditionally used by humans but seldom well managed. Participatory management initiatives flourished from partnerships between the government and NGOs to manage protected areas. Results from this study show that although stationary resources such as clams may favor comanagement initiatives, achieving success is not easy. Like other coastal fishing communities, the case studies presented show that a low level of education and limited prior experiences with community organization are strong barriers to fisheries comanagement.

Gelcich et al. (2013) present a contribution to fisheries economics in the context of using local experiments in comanagement systems. Unionized and nonunionized fishers were considered, and the experimental subjects were artisanal fishers who harvest 
benthic resources along the coast of central Chile. The authors found that groups of subjects from high-performance fishing unions behaved very cooperatively in the experiment, while nonunionized fishers, who rarely cooperate in the field, showed almost no cooperation in the experiment. Results presented regarding the effects of external enforcement in the highperformance unions illustrate how comanagement institutions can succeed only if they are accompanied by a virtuous interaction between local and higher levels of governance.

Maldonado and Moreno-Sánchez (2014) propose an Index of Adaptive Capacity (IAC) of fishing communities that can be estimated at the local scale in the context of establishing marine protected areas. The index captures current relationships between communities and the natural environment, incorporates socioeconomic conditions, and identifies formal and informal institutions. These components interact in a dynamic context, which influences strategies, capacities, and assets available to communities for coping with change. The authors conclude that the most relevant application of this IAC is that it allows decisionmakers to identify needs in order to prioritize actions when budgets are limited and when there are conflicting goals. The authors conclude that any policy aimed at enhancing conservation within marine protected areas should consider strategies that improve the conditions for local communities.

Finally, climate change, which will complicate the challenges faced by global fisheries (Worm et al. 2006, Allison et al. 2009, McClanahan and Cinner 2012), is also addressed in this Special Feature. Defeo et al. (2013) address some of the key impacts of climate change on marine social-ecological systems in LAC by using a case study approach. The authors point out that the data series used for the case studies analyzed confirms a dramatic impact of climate variability on the stocks and fisheries investigated. However, the results also suggest that spatially oriented management tools could ameliorate ecosystem impacts caused by increasing thermal anomalies associated with global warming.

\section{CONCLUSIONS}

Improving ecosystem stewardship of marine social-ecological systems in Latin American requires improved cooperation, and the case studies presented provide an important illustration of how such cooperation can be achieved. Combined, they describe social processes, leadership, and institutional and organizational changes of adaptive fisheries governance. The field of resilience research is still in an explorative phase in the region, and our ambition with this Special Feature is that the discoveries presented may stimulate additional research in this field, including increased international cooperation with Latin American scientists. Exciting scientific development of the region includes the establishment of the South American Institute for Resilience and Sustainability Studies-SARA(S) ${ }^{2}$ (http://saras-institute.org/), which was designed to catalyze high-impact science that can enhance the long-term resilience of Latin American's socialecological systems.

Responses to this article can be read online at: http://www.ecologyandsociety.org/issues/responses. $\mathrm{php} / 5949$

\section{Acknowledgments:}

We wish to thank all authors and reviewers for their valuable contributions. We also appreciate the support of the Editors-inChief of Ecology and Society, and in particular, Jennifer Miner, who kindly assisted us during the publication process of the Special Feature. We acknowledge valuable discussions and suggestions during the Subregional Workshop for South America on Valuation and Incentive Measures (Santiago de Chile, May 14-17, 2012) organized by the United Nations Environmental Programme and the Convention on Biological Diversity, and the XIII Workshop of the Latin American and the Caribbean Environmental Economics Program (San José de Costa Rica, May 19-22, 2012). SV was funded by Pedro Barrié de La Maza Foundation, the Campus do Mar-International Campus of Excellence, and the Norwegian Research Council. HÖ was funded by Mistra, through a core grant to Stockholm Resilience Centre, the Nippon Foundation, and FORMAS.

\section{LITERATURE CITED}

Allison, E., L. Perry, M. C. Badjeck, W. N. Adger, K. Brown, D. Conway, A. S. Halls, G. M. Pilling, J. D. Reynolds, N. L. Andrew, and N. K. Dulvy. 2009. Vulnerability of national economies to the impacts of climate change on fisheries. Fish and Fisheries 1:219.

Arias Schreiber, M., and A. Halliday. 2013. Uncommon among the commons? Disentangling the sustainability of the Peruvian anchovy fishery. Ecology and Society 18(2):12. http://dx.doi. org/10.5751/ES-05319-180212

Basurto, X., A. Bennett, A. Hudson Weaver, S. Rodriguez-Van Dyck, and J.-S. Aceves-Bueno. 2013. Cooperative and noncooperative strategies for small-scale fisheries' selfgovernance in the globalization era: implications for conservation. Ecology and Society 18(4): 38. http://dx.doi. org/10.5751/ES-05673-180438

Bovarnick, A., F. Alpízar, and C. Schnell, editors. 2010. The importance of biodiversity and ecosystems in economic growth and equity in Latin America and the Caribbean: an economic valuation of ecosystems. United Nations Development Programme, Washington, D.C., USA.

Boyd, C. 2010. Fisheries sector. Pages 83-126 in A. Bovarnick, F. Alpizar, and C. Schnell, editors. The importance of biodiversity and ecosystems in economic growth and equity in Latin America and the Caribbean: an economic valuation of ecosystems. United Nations Development Programme, Washington, D.C., USA.

Castilla, J. C., and O. Defeo. 2001. Latin American benthic shellfisheries: emphasis on co-management and experimental practices. Reviews in Fish Biology and Fisheries 11:1-30. http://dx. doi.org/10.1023/A:1014235924952

Chapin, F. S., S. R. Carpenter, G. P. Kofinas. C. Folke, N. Abel, W. C. Clark, P. Olsson, D. M. Stafford Smith, B. Walker, O. R. Young, F. Berkes, R. Biggs, J. M. Grove, R. L. Naylor, E. Pinkerton, W. Steffen, and F. J. Swanson. 2010. Ecosystem stewardship: sustainability strategies for a rapidly changing planet. Trends in Ecology \& Evolution 25:241-249. http://dx.doi. org/10.1016/j.tree.2009.10.008 
Chapin F. S., III, S. T. A. Pickett, M. E. Power, R. B. Jackson, D. M. Carter, and C. Duke. 2011. Earth stewardship: a strategy for social-ecological transformation to reverse planetary degradation. Journal of Environmental Studies and Sciences 1:44-53. http://dx. doi.org/10.1007/s13412-011-0010-7

Cinner, J. E., T. R. McClanahan, M. A. MacNeil, N. A. J. Graham, T. M. Daw, A. Mukminin, D. A. Feary, A. L. Rabearisoa, A. Wamukota, N. Jiddawi, S. J. Campbell, A. H. Baird, F. A. Januchowski-Hartley, S. Hamed, R. Lahari, T. Morove, and J. Kuange. 2012. Comanagement of coral reef social-ecological systems. Proceedings of the National Academy of Sciences of the United States of America 109:5219-5222. http://dx.doi. org/10.1073/pnas.1121215109

Cinti, A., J. Duberstein, E. Torreblanca, and M. Moreno-Báez. 2014. Overfishing drivers and opportunities for recovery in smallscale fisheries of the Midriff Islands Region, Gulf of California, Mexico: the roles of land and sea institutions in fisheries sustainability. Ecology and Society 19(1):15. http://dx.doi. org/10.5751/ES-05570-190115

Crèpin, A. S., B. Walker, S. Polasky, W. Steffen, V. Galaz, C. Folke, and J. Rockström. 2011. Global dynamics, multiple shocks and resilience planetary stewardship and catastrophic shifts in the Earth system. Beijer Discussion Paper Series No. 228. Beijer Institute of Ecological Economics, Royal Swedish Academy of Sciences.

Defeo, O., and J. C. Castilla. 2005. More than one bag for the world fishery crisis and keys for co-management successes in selected artisanal Latin American shellfisheries. Review of Fish Biology and Fisheries 15:265-283. http://dx.doi.org/10.1007/ s11160-005-4865-0

Defeo, O., and J. C. Castilla. 2012. Governance and governability of coastal shellfisheries in Latin America and the Caribbean: multi-scale emerging models and effects of globalization and climate change. Current Opinion in Environmental Sustainability 4:344-350. http://dx.doi.org/10.1016/j.cosust.2012.05.002

Defeo, O., M. Castrejón, L. Ortega, A. M. Kuhn, N. L. Gutiérrez, and J. C. Castilla. 2013. Impacts of climate variability on Latin American small-scale fisheries. Ecology and Society 18(4): 30. http://dx.doi.org/10.5751/ES-05971-180430

Folke, C., Å. Jansson, J. Rockström, P. Olsson, S. R. Carpenter, F. S. Chapin, III, A.-S. Crèpin, G. Daily, K. Danell, J. Ebbesson, T. Elmqvist, V. Galaz, F. Moberg, M. Nilsson, H. Österblom, E. Ostrom, A. Persson, G. Peterson, S. Polasky, W. Steffen, B. Walker, and F. Westley. 2011. Reconnecting to the biosphere. Ambio 40:719-738. http://dx.doi.org/10.1007/s13280-011-0184-y

Food and Agriculture Organization of the United Nations (FAO). 2012. State of the world's fisheries and aquaculture 2012. Food and Agriculture Organization of the United Nations, Rome, Italy.

Gelcich, S., R. Guzman, C. Rodriguez-Sickert, J. C. Cardenas, and J. C. Cástilla. 2013. Exploring external validity of common pool resource experiments: insights from artisanal benthic fisheries in Chile. Ecology and Society 18(3):2. http://dx.doi. org/10.5751/ES-05598-180302

Gelcich, S., T. P. Hughes, P. Olsson, C. Folke, O. Defeo, M. Fernández, S. Foale, L. H. Gunderson, C. Rodríguez-Sickert, M. Scheffer, R. S. Steneck, and J. C. Castilla. 2010. Navigating transformations in governance of Chilean marine coastal resources. Proceedings of the National Academy of Sciences of the United States of America 107:16794-16799. http://dx.doi. org/10.1073/pnas.1012021107

Gutiérrez, N., R. Hilborn, and O. Defeo. 2011. Leadership, social capital and incentives promote successful fisheries. Nature 470:386-389. http://dx.doi.org/10.1038/nature09689

Hilborn, R., J. M. Orensanz, and A. Parma. 2005. Institutions, incentives and the future of fisheries. Philosophical Transactions of the Royal Society B: Biological Sciences 360:47-57. http://dx. doi.org/10.1098/rstb.2004.1569

Hilborn, R., and C. Walters. 1992. Quantitative fisheries stock assessment, choice, dynamics and uncertainty. Chapman and Hall, New York, USA.

Hughes, T. P., D. R. Bellwood, C. Folke, R. S. Steneck, and J. Wilson. 2005. New paradigms for supporting the resilience of marine ecosystems. Trends in Ecology \& Evolution 20:380-386. http://dx.doi.org/10.1016/j.tree.2005.03.022

Maldonado, J. H., and R. del Pilar Moreno-Sánchez. 2014. Estimating the adaptive capacity of local communities at marine protected areas in Latin America: a practical approach. Ecology and Society 19(1): 16. http://dx.doi.org/10.5751/ES-05962-190116

McClanahan, T. R., and J. Cinner. 2012. Adapting to a changing environment. Confronting the consequences of climate change. Oxford University Press, New York, USA.

Munro, G. 1979. The optimal management of transboundary renewable resources. Canadian Journal of Economics 12:353-376. http://dx.doi.org/10.2307/134727

Orensanz, J. M., A. Parma, G. Jerez, N. Barahona, M. Montecinos, and I. Elías. 2005. What are the key elements for the sustainability of "S- fisheries"? Insights from Latin America. Bulletin of Marine Science 76(2):527-566.

Ostrom, E. 1990. Governing the common: the evolution of institutions for collective actions. Cambridge University Press, Cambridge, UK. http://dx.doi.org/10.1017/CBO9780511807763

Polasky, S., N. Tarui, G. M. Ellis, and C. F. Mason. 2006. Cooperation in the commons. Economic Theory 29(1):71-88. http://dx.doi.org/10.1007/s00199-005-0018-x

Rocha, L. M., and E. Pinkerton. 2015. Comanagement of clams in Brazil: a framework to advance comparison. Ecology and Society 20(1): 7. http://dx.doi.org/10.5751/ES-07095-200107

Salas, S., R. Chuenpagdee, J. C. Seijo, and A. Charles. 2007. Challenges in the assessment and management of small-scale fisheries in Latin America and the Caribbean. Fisheries Research 87(1):5-16. http://dx.doi.org/10.1016/j.fishres.2007.06.015

Villasante, S. 2012. Better fishery management could significantly increase economic returns, Argentina. Beijer Discussion Papers No. 186; 331. Beijer International Institute of Ecological Economics, Royal Swedish Academy of Sciences, Sweden.

Worm, B., E. B. Barbier, N. Beaumont, J. E. Duffy, C. Folke, B. S. Halpern, J. B. C. Jackson, H. K. Lotze, F. Micheli, S. R. Palumbi, E. Sala, K. A. Selkoe, J. J. Stachowicz, and R. Watson. 2006. Impacts of biodiversity loss on ocean ecosystem services. Science 314:787-790. http://dx.doi.org/10.1126/science.1132294 